\title{
CASSAVA WASTE AS AN ADDITIONAL SOURCE OF ORGANIC COMPOSES
}

\author{
Nadhia Nurul Haq ${ }^{a *}$ \\ ${ }^{a)}$ Madrasah Aliyah Negeri 2, Bogor, Indonesia \\ ${ }^{*}$ Corresponding Author: nadhianh15@gmail.com
}

Article history: received 28 July 2019; revised 02 August 2019; accepted 25 August 2019

\begin{abstract}
Abstrak. This research aims to determine the effectiveness of adding powder cassava waste in compost making. Versatile in making compost. This research uses a Completely Randomized Design consisting of 4 settings with 3 replications with different amounts. The parameters chosen were composting temperature, composting fermentation time period, composting humidity, acidity composting and continued with water spinach growth vegetative test. Data analysis using one-way ANOVA test and further tests with Duncan's Multi Range Test at $1 \%$ significance level. Research results for 30 days in making compost with cassava powder complement, like fertilizer after growth, Vegetative ground spinach (ipomoea reptans) did not show a significant effect or no effect
\end{abstract}

Keywords: effectiveness, cassava, compost

\section{INTRODUCTION}

Industry is a human endeavor so that goods derived from nature can be utilized as products that have a sale value and have a favorable economic prospect. Material from nature has chemical compounds that can be used for certain purposes, for example as food, feed, fuel, fertilizer, cosmetics, etc. so that human life becomes more comfortable. A chemical industry must pay attention to environmental sustainability and it is hoped that the processing of industrial materials is safe for the environment, and the products produced are environmentally friendly [1].

Garbage is a by-product of unused human activity. The amount of waste produced in a certain area is proportional to the population, type of activity, and the level of consumption of the population of goods / material. The greater the population or the level of consumption of goods, the greater the volume of waste produced (Purwendro [2]).

Cassava waste is one of the biomass material from agricultural residues that has not been widely used and has good potential as an adsorbent. Cellulose is a major component of plants [3], this plant material found in the cell walls of fruits and vegetables such as wood, branches, and leaves, can not be digested by humans. Cellulose that passes through the digestive system of food is not changed, but is used as dietary fiber that is received by the human digestive system which is not good. Cassava skin waste is agricultural residues that are found in abundant quantities in various regions in Indonesia, including Bogor. Cassava varieties that are traditionally widely used in Bogor are Manihot esculenta Crantz Adira 2 grown in Cimahpar, Bogor, Karikil from Cililin in West Bandung and Sao Pedro Petrocassava from Cisarua, Bogor [4].

Compost is the result of decomposition, weathering, and decay of organic material such as animal dung, leaves, and other organic materials. compost material is available around us in various forms. some examples of compost material are stems, leaves, plant roots, and everything that can be destroyed (Soeryoko [5]).

Compost is the result of fermentation or decomposition of organic materials such as plants, animals, or other organic waste. Compost used as fertilizer is also called organic fertilizer because its constituents consist of organic materials (Indriani [6]). Organic Waste Organic waste comes from living things [7], both humans, animals and plants. Organic waste itself is divided into wet organic waste and dry organic waste. The term wet organic waste is meant to have high water content. For example fruit skin and vegetable waste. While materials that include dry organic waste are other organic materials that have a small water content. For example, dry organic waste includes paper, wood, or tree branches, and dried leaves (Sucipto [8]). In principle, almost all organic waste can be composted. The waste can be in the form of crop residues, agricultural industrial waste, livestock manure, or litter or leaves. The rest of the harvest can be in the form of straw, crop residues, leaf vegetable residues, and so forth. Agricultural industrial wastes include tofu waste, cassava waste powder, and others. Grasses can also be composted. Organic waste that should not be composted includes hardwood, bamboo, bones and horns. These materials take a long time to compost, so they should be composted separately from soft materials (Nurheti \& Isroi [9]).

\section{RESEARCH METHODS}

Research Design This type of research is a pure experiment (True Experiment), with a completely 
randomized design design consisting of 4 treatments with 3 repetitions. The research design can be seen in Figure 1.

\begin{tabular}{|c|c|c|}
\hline $\mathrm{P}_{3}$ & $\mathrm{P}_{1}$ & $\mathrm{P}_{3}$ \\
\hline $\mathrm{P}_{2}$ & $\mathrm{P}_{0}$ & $\mathrm{P}_{2}$ \\
\hline $\mathrm{P}_{1}$ & $\mathrm{P}_{3}$ & $\mathrm{P}_{1}$ \\
\hline $\mathrm{P}_{0}$ & $\mathrm{P}_{2}$ & $\mathrm{P}_{0}$ \\
\hline simplo & duplo & triplo \\
\hline
\end{tabular}

Figure.1 Research design Description:

1. $\mathrm{P}$ 0: $5 \mathrm{~kg}$ organic waste $+1 \mathrm{~kg}$ manure $+\mathrm{EM} 4$ (2 $\mathrm{ml}$ of EM4 mixed with $10 \mathrm{~g}$ of sugar and 1 liter of water).

2. $\mathrm{P} 1: 3.75 \mathrm{~kg}$ organic waste $+1 \mathrm{~kg}$ of manure $+1.25 \mathrm{~kg}$ cassava waste powder + EM 4 (2 ml of EM4 mixed with $10 \mathrm{~g}$ of sugar and 1 liter of water).

3. $\mathrm{P}$ 2: $2.50 \mathrm{~kg}$ organic waste $+1 \mathrm{~kg}$ of manure $+2.50 \mathrm{~kg}$ cassava waste powder + EM 4 (2 ml of EM4 mixed with $10 \mathrm{~g}$ of sugar and 1 liter of water).

4. $\mathrm{P}$ 3: $1.25 \mathrm{~kg}$ organic waste $+1 \mathrm{~kg}$ of manure $+2.75 \mathrm{~kg}$ of cassava waste powder + EM 4 (2 ml of EM4 mixed with $10 \mathrm{~g}$ of sugar and 1 liter of water).

\section{RESULTS AND DISCUSSION}

The composting process is carried out for 30 days, for each day observation and data collection are carried out. Data taken daily are composting $\mathrm{pH}$, composting temperature, composting humidity and composting fermentation time. The measurement uses a measuring instrument namely Thermohygrometer and Soil Tester. From the above data, we can see that on the 30th day there were signs of good composting, because they were nearing the optimum $\mathrm{pH}$, optimum temperature and optimum humidity. The smell of compost on the 30th day has no odor and resembles soil, the color of compost is also blackish brown, if it is shredded it will break easily. then proceed with testing on the growth of spinach to see the effectiveness of the use of cassava waste powder in compost fertilizer.

Vegetative growth of ground spinach the next step carried out was the testing of compost on the growth of ground spinach. From the observations made for 14 days, recapitulation of Kangkung vegetative growth is as Table 1.

From the results of observations on the effectiveness of the addition of cassava waste powder in compost making and continued testing on the growth of water spinach, that in the third treatment pattern of water spinach growth is better than other treatments, the stem length looks longer than in other treatments and the number of leaves is more than the treatment the other. This is because the ratio of the amount of organic waste and the amount of cassava waste powder in the third treatment $(\mathrm{P} 2)$ amounts to the same ie
$2.50 \mathrm{~kg}$ of organic waste and $2.50 \mathrm{~kg}$ of cassava waste powder. based on Rukiyati's [10] research, regarding effective composting techniques for controlling household organic waste, a number of bacteria convert household organic waste into simpler materials that are easily absorbed by plants.

Table 1. Recapitulation of average growth of Vegetables ground spinach

\begin{tabular}{|c|c|c|}
\hline treatment & stem length $(\mathrm{cm})$ & number of leaves \\
\hline P0 & 18,4 & 4 \\
\hline P1 & 19,2 & 3 \\
\hline P2 & 19,6 & 5 \\
\hline P3 & 20,7 & 4 \\
\hline
\end{tabular}

For further testing, data analysis was performed using one-way ANOVA with a level of $1 \%$. ANOVA oneway test results can be seen in the table 2 .

Table 2 Results of One-Way ANOVA test on ground spinach vegetative growth test

\begin{tabular}{|c|c|c|c|c|c|}
\hline & Time & treatment & $\mathrm{P}$ & $\begin{array}{c}\text { Sig. } \\
(a)\end{array}$ & Status \\
\hline $\begin{array}{c}\text { stalk } \\
\text { length }\end{array}$ & 14 day & $\mathrm{P} 0$ & 0,136 & 0,01 & $\begin{array}{c}\text { not significantly } \\
\text { different }\end{array}$ \\
\hline & & $\mathrm{P} 1$ & 0,136 & 0,01 & $\begin{array}{c}\text { not significantly } \\
\text { different }\end{array}$ \\
\hline & & $\mathrm{P} 3$ & 0,136 & 0,01 & $\begin{array}{c}\text { not significantly } \\
\text { different }\end{array}$ \\
\hline $\begin{array}{c}\text { stalk } \\
\text { length }\end{array}$ & 14 day & $\mathrm{P} 0$ & 0,160 & 0,01 & $\begin{array}{c}\text { not significantly } \\
\text { different }\end{array}$ \\
\hline & & $\mathrm{P} 1$ & 0,160 & 0,01 & $\begin{array}{c}\text { not significantly } \\
\text { different }\end{array}$ \\
\hline & & $\mathrm{P} 2$ & 0,160 & 0,01 & $\begin{array}{c}\text { not significantly } \\
\text { different }\end{array}$ \\
\hline
\end{tabular}

Based on Table 2 of the four treatments with different treatment patterns and tested with one-way ANOVA with a significance level of $1 \%$, aimed at the results of the effectiveness of making compost and continued testing on the growth of water spinach on the fourteenth day the results are not different [11], this because the value of $p$ is greater than the value of the significance level (>0.01), then the decision accepts Ho thus it can be concluded that making compost does not affect the growth of water spinach.

After composting is complete, the composting $\mathrm{pH}$ data obtained for 30 days is analyzed using One-Way ANOVA with a level of $1 \%$. One-Way ANOVA test results can be seen in the table 3 .

Based on Table 3 of the four treatments with different treatment patterns and tested with one-way ANOVA with a significance level of $1 \%$, it shows that the results of the effectiveness of making compost fertilizer day zero, day ten, day twenty and day thirty results, this is because $p$ value is greater than the value of significance 
level (> 0.01), then the decision accept $\mathrm{H} 0$ thus it can be concluded that the addition of cassava waste powder in compost fertilizer production has no effect in making compost fertilizer. based on research by Rukiyati [10],

Table 3 Results of the one-way ANOVA test on the observation of composting ph

\begin{tabular}{|c|c|c|c|c|}
\hline Time & treatment & $\mathrm{P}$ & $\begin{array}{l}\text { Sig. } \\
\text { (a) }\end{array}$ & Status \\
\hline \multirow[t]{4}{*}{0 day } & P0 & 0,755 & 0,01 & $\begin{array}{c}\text { not significantly } \\
\text { different }\end{array}$ \\
\hline & P1 & 0,755 & 0,01 & $\begin{array}{c}\text { not significantly } \\
\text { different }\end{array}$ \\
\hline & $\mathrm{P} 2$ & 0,755 & 0,01 & $\begin{array}{c}\text { not significantly } \\
\text { different }\end{array}$ \\
\hline & P3 & 0,755 & 0,01 & $\begin{array}{c}\text { not significantly } \\
\text { different }\end{array}$ \\
\hline \multirow[t]{4}{*}{10 days } & P0 & 0,863 & 0,01 & $\begin{array}{c}\text { not significantly } \\
\text { different }\end{array}$ \\
\hline & P1 & 0,863 & 0,01 & $\begin{array}{c}\text { not significantly } \\
\text { different }\end{array}$ \\
\hline & $\mathrm{P} 2$ & 0,863 & 0,01 & $\begin{array}{c}\text { not significantly } \\
\text { different }\end{array}$ \\
\hline & P3 & 0,863 & 0,01 & $\begin{array}{c}\text { not significantly } \\
\text { different }\end{array}$ \\
\hline \multirow[t]{4}{*}{20 days } & P0 & 0,837 & 0,01 & $\begin{array}{c}\text { not significantly } \\
\text { different }\end{array}$ \\
\hline & P1 & 0,837 & 0,01 & $\begin{array}{c}\text { not significantly } \\
\text { different }\end{array}$ \\
\hline & $\mathrm{P} 2$ & 0,837 & 0,01 & $\begin{array}{c}\text { not significantly } \\
\text { different }\end{array}$ \\
\hline & P3 & 0,837 & 0,01 & $\begin{array}{c}\text { not significantly } \\
\text { different }\end{array}$ \\
\hline \multirow[t]{4}{*}{30 days } & P0 & 0,180 & 0,01 & $\begin{array}{c}\text { not significantly } \\
\text { different }\end{array}$ \\
\hline & P1 & 0,180 & 0,01 & $\begin{array}{c}\text { not significantly } \\
\text { different }\end{array}$ \\
\hline & P2 & 0,180 & 0,01 & $\begin{array}{c}\text { not significantly } \\
\text { different }\end{array}$ \\
\hline & P3 & 0,180 & 0,01 & $\begin{array}{c}\text { not significantly } \\
\text { different }\end{array}$ \\
\hline
\end{tabular}

about effective composting techniques for controlling household organic waste, $\mathrm{pH}$ in the composting process with bio-activator cow dung and EM4, at the beginning of low $\mathrm{pH}$ decomposition, because a number of bacteria convert organic matter into organic acids, but on days The next day the $\mathrm{pH}$ rose because a number of bacteria reused these organic acids as an energy source. According to Indriani [6], acidity or ph in the compost heap also affects the activity of microorganisms. A good $\mathrm{pH}$ range for composting is around 6.57 .5 (neutral). Composting Temperature, the composting temperature data obtained for 30 days was analyzed using One-Way ANOVA with a level of $1 \%$. One-Way ANOVA test results can be seen in the table 4 .

Based on Table 4 of the four treatments with different treatment patterns and tested by one-way ANOVA with a significance level of $1 \%$, aimed at the results of the effectiveness of making compost fertilizer day zero, day ten, day twenty and day thirty results, this is in because the $p$ value is greater than the significance level value (>0.01), then the decision accepts $\mathrm{H} 0$ thus it can be concluded that the addition of cassava waste powder in compost fertilizer production does not affect the making of compost fertilizer. based on research by Rukiyati [10], regarding effective composting techniques to control household organic waste, the temperature in the composting process with bioactivator cow dung and EM4 is always changing, where on the 5th day it has begun to increase until the 20th, which indicates the decomposition process has begun to run because a number of bacteria convert household organic waste into simpler materials so that it is easily absorbed by plants, then in the following days the temperature decreases because the organic material to be composed has begun to decrease.

Table 4 Results of the one-way ANOVA test on observing composting temperature

\begin{tabular}{|c|c|c|c|c|}
\hline Time & treatment & $\mathrm{P}$ & $\begin{array}{l}\text { Sig. } \\
\text { (a) }\end{array}$ & Status \\
\hline \multirow[t]{4}{*}{0 day } & P0 & 0,855 & 0,01 & $\begin{array}{c}\text { not significantly } \\
\text { different }\end{array}$ \\
\hline & P1 & 0,855 & 0,01 & $\begin{array}{c}\text { not significantly } \\
\text { different }\end{array}$ \\
\hline & P2 & 0,855 & 0,01 & $\begin{array}{c}\text { not significantly } \\
\text { different }\end{array}$ \\
\hline & P3 & 0,855 & 0,01 & $\begin{array}{c}\text { not significantly } \\
\text { different }\end{array}$ \\
\hline \multirow[t]{4}{*}{10 days } & P0 & - & 0,01 & $\begin{array}{c}\text { not significantly } \\
\text { different }\end{array}$ \\
\hline & P1 & - & 0,01 & $\begin{array}{c}\text { not significantly } \\
\text { different }\end{array}$ \\
\hline & P2 & - & 0,01 & $\begin{array}{c}\text { not significantly } \\
\text { different }\end{array}$ \\
\hline & P3 & - & 0,01 & $\begin{array}{c}\text { not significantly } \\
\text { different }\end{array}$ \\
\hline \multirow[t]{4}{*}{20 days } & P0 & - & 0,01 & $\begin{array}{c}\text { not significantly } \\
\text { different }\end{array}$ \\
\hline & P1 & - & 0,01 & $\begin{array}{c}\text { not significantly } \\
\text { different }\end{array}$ \\
\hline & P2 & - & 0,01 & $\begin{array}{c}\text { not significantly } \\
\text { different }\end{array}$ \\
\hline & P3 & - & 0,01 & $\begin{array}{c}\text { not significantly } \\
\text { different }\end{array}$ \\
\hline \multirow[t]{4}{*}{30 days } & P0 & - & 0,01 & $\begin{array}{c}\text { not significantly } \\
\text { different }\end{array}$ \\
\hline & P1 & - & 0,01 & $\begin{array}{c}\text { not significantly } \\
\text { different }\end{array}$ \\
\hline & P2 & - & 0,01 & $\begin{array}{c}\text { not significantly } \\
\text { different }\end{array}$ \\
\hline & P3 & - & 0,01 & $\begin{array}{c}\text { not significantly } \\
\text { different }\end{array}$ \\
\hline
\end{tabular}

According to Indriani [6], too high a temperature will result in the death of microorganisms. When temperatures are relatively low, microorganisms cannot work or are dormant. The activity of microorganisms in the process of composting also generates heat so that to maintain an optimal temperature often reversals are carried out. Composting Humidity, the composting humidity data obtained for 30 days was analyzed using One-Way ANOVA with a level of $1 \%$. One-Way ANOVA test results can be seen in the table 5 .

Based on Table 5 of the four treatments with different treatment patterns and tested by one-way ANOVA with a significance level of $1 \%$, shows that the results of the effectiveness of making compost zero days, ten days, twenty days and thirty days the results, this is because the value of $p$ is greater than the significance level $(>0.01)$, then the decision accepts $\mathrm{H} 0$ thus it can be concluded that the addition of cassava waste powder in compost making 
does not affect the vegetative growth of Kangkung plants. based on research by Rukiyati [10], about effective composting techniques for controlling household organic waste, humidity in the composting process with bioactivators cow dung and EM4 on the first day of high humidity due to the pile of garbage in humid conditions, but in the following days humidity has begun decrease because every 5 days a reversal is held which is useful to put fresh air in the garbage pile so that the humidity is reduced.

Table 5 Results of the one-way ANOVA test for observing composting humidity

\begin{tabular}{|c|c|c|c|c|}
\hline Time & treatment & $\mathrm{P}$ & $\begin{array}{l}\text { Sig. } \\
\text { (a) }\end{array}$ & Status \\
\hline \multirow[t]{4}{*}{0 day } & P0 & 0,055 & 0,01 & $\begin{array}{c}\text { not significantly } \\
\text { different }\end{array}$ \\
\hline & P1 & 0,055 & 0,01 & $\begin{array}{c}\text { not significantly } \\
\text { different }\end{array}$ \\
\hline & P2 & 0,055 & 0,01 & $\begin{array}{c}\text { not significantly } \\
\text { different }\end{array}$ \\
\hline & P3 & 0,055 & 0,01 & $\begin{array}{c}\text { not significantly } \\
\text { different }\end{array}$ \\
\hline \multirow[t]{4}{*}{10 days } & P0 & 0,525 & 0,01 & $\begin{array}{c}\text { not significantly } \\
\text { different }\end{array}$ \\
\hline & P1 & 0,525 & 0,01 & $\begin{array}{c}\text { not significantly } \\
\text { different }\end{array}$ \\
\hline & $\mathrm{P} 2$ & 0,525 & 0,01 & $\begin{array}{c}\text { not significantly } \\
\text { different }\end{array}$ \\
\hline & P3 & 0,525 & 0,01 & $\begin{array}{c}\text { not significantly } \\
\text { different }\end{array}$ \\
\hline \multirow[t]{4}{*}{20 days } & P0 & 0,546 & 0,01 & $\begin{array}{c}\text { not significantly } \\
\text { different }\end{array}$ \\
\hline & P1 & 0,546 & 0,01 & $\begin{array}{c}\text { not significantly } \\
\text { different }\end{array}$ \\
\hline & $\mathrm{P} 2$ & 0,546 & 0,01 & $\begin{array}{c}\text { not significantly } \\
\text { different }\end{array}$ \\
\hline & P3 & 0,546 & 0,01 & $\begin{array}{c}\text { not significantly } \\
\text { different }\end{array}$ \\
\hline \multirow[t]{4}{*}{30 days } & P0 & 0,189 & 0,01 & $\begin{array}{c}\text { not significantly } \\
\text { different }\end{array}$ \\
\hline & P1 & 0,189 & 0,01 & $\begin{array}{c}\text { not significantly } \\
\text { different }\end{array}$ \\
\hline & P2 & 0,189 & 0,01 & $\begin{array}{c}\text { not significantly } \\
\text { different }\end{array}$ \\
\hline & P3 & 0,189 & 0,01 & $\begin{array}{c}\text { not significantly } \\
\text { different }\end{array}$ \\
\hline
\end{tabular}

According to Indriani [6], in general, microorganisms can work with humidity around 40-50\%. These conditions need to be maintained so that microorganisms can work optimally. Lower or higher humidity can cause microorganisms not to develop or die.

\section{CONCLUSION}

Based on the results of research that has been carried out for four weeks in the manufacture of compost with the addition of cassava waste powder showed that there were no significant differences followed by testing for 14 days on stem growth and the number of Kangkung leaves (ipomoea reptans). This means that there is no effect of making compost on the growth of water spinach (ipomoea reptans). Suggestions Cassava waste powder used for research into the effectiveness of the addition of cassava waste powder in making compost comes from cassava waste. Therefore cassava waste powder needs a relatively long time to be decomposed by bacteria in the composting process. While the composting time in this research is 30 days, so for the next researcher or farmers it is recommended that the composting time is longer.

\section{REFERENSI}

[1] P. Citroreksoko, A. Taufik, A. Murharini, S. Purawisastra, and Y. Suchyadi, 2012. Kimia Terapan, 1st ed. Jakarta: Universitas Terbuka..

[2] Purwendro, S. 2007. Mengolah Sampah Untuk Pupuk Dan Pestisida Organik. penebar swadaya : Jakarta

[3] L. Heliawati, Y. Suchyadi, and A. Iryani, 2018. Kimia Organik 2, 01 ed. Bogor: LPPM Universitas Pakuan..

[4] W. Diana et al., "Cytotoxic effects of cassava (Manihot esculenta Crantz), Adira-2, karikil and sao pedro petro varieties against P-388 murine leukemia cells," Res. J. Chem. Environ., vol. 22, no. Special issue II, pp. 206-208, 2018.

[5] Soeryoko, 2011. H Kiat Pintar Memproduksi Kompos Dengan Pengurai Buatan Sendiri. ANDI : Yogyakarta.

[7] L. Heliawati, Y. Suchyadi, and A. Iryani, 2018. Kimia Organik 1, 01 ed. Bogor: LPPM Universitas Pakuan.

[6] Indriani, Y. 2012. Membuat Pupuk Secara Kilat. Penebar swadaya : Jakarta

[8] Sucipto, C. 2012. Teknologi Pengolahan Daur Ulang Sampah. Gosyen Publishing : Yogyakarta.

[9] Nurheti \& Isroi. 2009. Kompos Cara Mudah, Murah, Dan Cepat Menghasilkan Kompos. ANDI : Yogyakarta.

[10] Rukiyati, 2011. teknik pengomposan efektif untuk mengendalikan sampah organik rumah tangga. Penebar Swadaya : Jakarta.

[11] Soeprapto, 1993. Bertanam Kangkung. Penebar Swadaya : Jakarta. 